\title{
COMMENT
}

\section{Diving behaviour of green turtles: dive depth, dive duration and activity levels}

\author{
G. C. Hays ${ }^{1, *}$, S. Hochscheid ${ }^{2}$, A. C. Broderick ${ }^{1}$, B. J. Godley ${ }^{1}$, J. D. Metcalfe ${ }^{3}$ \\ ${ }^{1}$ School of Biological Sciences, University of Wales Swansea, Singleton Park, Swansea SA2 8PP, United Kingdom \\ ${ }^{2}$ Department of Zoology, Tillydrone Avenue, Aberdeen AB24 2TZ, United Kingdom \\ ${ }^{3}$ The Centre for Environment, Fisheries and Aquaculture Science, Lowestoft Laboratory, Lowestoft NR33 0HT, United Kingdom
}

Hochscheid et al. (1999) used time-depth recorders (TDRs) and activity recorders (Hochscheid \& Wilson 1999) to examine diving behaviour and activity of green turtles during their internesting period at Cyprus. Turtles were found to spend a large proportion of time undertaking dives with a characteristic 'U-shaped' profile, i.e. dives where individuals remained at a fixed depth for a long period, surfaced briefly and then descended to the same depth again. Information from the activity sensor suggested that some of these U-dives were associated with resting, others with benthic activity.

While TDRs have been extensively deployed on marine mammals and birds, their deployment on sea turtles is still in its infancy. We are only now starting to appreciate the wealth of information that these instruments can provide about free-living turtles. Unlike many marine mammals, shallow diving marine turtles - such as the green (Chelonia mydas) and loggerhead (Caretta caretta) turtles - use their lungs both to regulate their buoyancy and as a major $\mathrm{O}_{2}$ store (Milsom 1975, Lutcavage \& Lutz 1997). An individual clearly cannot be positively buoyant if it is to passively stay on the sea-bed, either resting or foraging. Since the lung volume will be reduced with increasing depth (due to gas compression in accordance with Boyle's law), a turtle is able to dive with a larger lung volume when diving deeper, and still attain negative buoyancy. Hence it might be predicted that there will be a general tendency for dive duration to increase with depth, due to this larger lung store; indeed this has been found in several studies (Minamikawa et al. 1996, Hochscheid et al. 1999, Hays et al. 2000). However, in addition to the total $\mathrm{O}_{2}$ store, dive duration may also be influenced by metabolic rate during the dive. In sim-

*E-mail: g.hays@swan.ac.uk plest terms, as the metabolic rate increases, dive duration might be expected to decrease. Hence we predict that dive duration may be linked to both dive depth and metabolic rate.

Testing this prediction is difficult, since standard TDRs provide no direct information on metabolic rate. However, Hochscheid et al. (1999) assessed the level of activity objectively using a 3-D compass system. Since the level of activity is likely to serve as a proxy for the metabolic rate, it would be predicted that dive duration will generally increase with dive depth and decrease with increasing activity. We tested this prediction using previously published data (Hochscheid et al.). Activity was calculated as the percentage of the bottom phase of each dive during which turtles were active, as defined by Hochscheid et al. We examined the activity levels associated with 200 randomly selected U-shaped dives for 2 turtles (Fig. 1a). For dives where the activity level was $0 \%$, dive duration increased with dive depth (Fig. 1b), in accord with the pattern recorded elsewhere. The residual variation from this regression was related to the activity level, with shorter dives occurring when activity levels were higher (Fig. 1c).

These results support the suggestion that dive duration in marine turtles is related to both dive depth and activity levels. Traditionally patterns of behaviour have been derived from TDRs by identifying different dive profiles. This is a valid procedure where different dive profiles are associated with different behaviours. However, in instances where the frequently observed U-dives may be associated with either rest or activity (e.g. in Cyprus), then the results presented here show that the dive duration as a function of the depth may help to distinguish different dive types. As such, for sea turtles information about the behaviour during a dive can be gained not only from the dive profile but also from the duration of the dives to particular depths. 

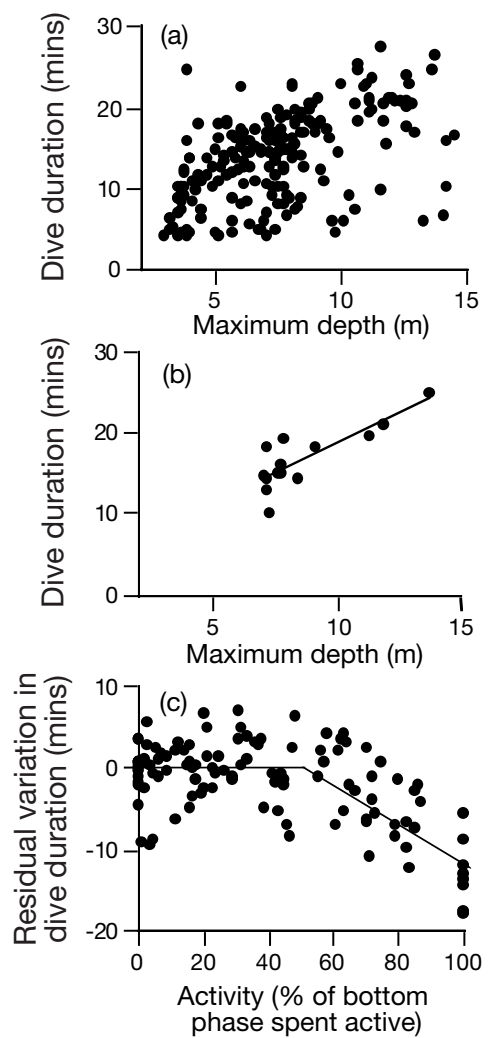

Fig. 1. Chelonia mydas. (a) For 200 dives of varying activity levels, the dive duration as a function of the dive depth. (b) For dives where activity levels were $0 \%$ (i.e. $100 \%$ of the bottom phase was spent inactive), the relationship between maximum depth and dive duration. Dive duration $(\mathrm{min})=$ 1.49 (maximum depth in $\mathrm{m})+3.85\left(F_{1,12}=129, \mathrm{r}^{2}=0.69, \mathrm{p}<\right.$ 0.001). (c) For all dives $>7 \mathrm{~m}$ [i.e. within the limits of the regression equation identified in (b)], the residual variation in dive duration calculated as the observed duration minus the value predicted from regression equation in (a), i.e. where the residual value is negative, the observed dive duration is shorter than the value predicted by the model for low activity dives. The fitted line assumes the residual variation was zero between 0 and $50 \%$ activity and then declined linearly and explains $48 \%$ of the residual variation $\left(F_{1,110}=103, \mathrm{p}<0.001\right)$

\section{LITERATURE CITED}

Hays GC, Adams CR, Broderick AC, Godley BJ, Lucas DJ, Metcalfe JD, Prior AA (2000) The diving behaviour of green turtles at Ascension Island. Anim Behav 59:577-586

Hochscheid S, Wilson RP (1999) A new method for the determination of at-sea activity in sea turtles. Mar Ecol Prog Ser 185:293-296

Hochscheid S, Godley BJ, Broderick AC, Wilson RP (1999) Reptilian diving: highly variable dive patterns in the green turtle Chelonia mydas. Mar Ecol Prog Ser 185:101-112

Lutcavage ME, Lutz PL (1997) Diving physiology. In: Lutz PL, Musick JA (eds) The biology of sea turtles. CRC Press, Boca Raton, p 277-296

Milsom WK (1975) Development of buoyancy control in juvenile Atlantic loggerhead turtles, Caretta c. caretta. Copeia 1975:758-762

Minamikawa S, Naito Y, Uchida I (1997) Buoyancy control and diving behaviour of the loggerhead turtle, Caretta caretta. J Ethol 15:109-118 